\title{
IMPACT OF THE PLATE DIAMETER ON THE VALUE OF THE PRE-COMPACTION STRESS IN SOILS WITH VARIED TEXTURAL GROUP ${ }^{1}$
}

\author{
Dariusz Błażejczak ${ }^{*}$, Jan B. Dawidowski \\ Department of Construction and Usage of Technical Devices, \\ West Pomeranian University of Technology in Szczecin
}

${ }^{*}$ Corresponding author: e-mail: dariusz.blazejczak@zut.edu.pl

\begin{tabular}{|c|c|}
\hline ARTICLE INFO & ABSTRACT \\
\hline $\begin{array}{l}\text { Article history: } \\
\text { Received: December } 2015 \\
\text { Received in the revised form: } \\
\text { January } 2016 \\
\text { Accepted: January } 2016\end{array}$ & \multirow{2}{*}{$\begin{array}{l}\text { The objective of the paper was to verify the previously obtained } \\
\text { results of research concerning the impact of the plate diameter on the } \\
\text { measured value of the pre-compaction stress of silt ( } N G \text { ), in conditions } \\
\text { of a wider range of soil types and their initial stage. The research was } \\
\text { carried out on samples with a diameter of } 100 \mathrm{~mm} \text { and height of } 30 \\
\text { mm produced from the soil material ( } M \text { ) or collected from the subsoil } \\
\text { of the selected soils ( } N N S \text { ) with the granulation type of: silt loam, } \\
\text { loam, light loam, sandy-clay soil. The following soils properties were } \\
\text { determined: the granulation type, density of the solid phase, content of } \\
\text { humus and calcium carbonate, reaction, plastic and liquid limit. The } \\
\text { properties of samples were described with moisture, dry density of } \\
\text { solid particles, porosity of aeration, degree of plasticity and degree of } \\
\text { saturation. The samples were loaded with a testing machine with plates } \\
\text { with varied diameters. The value of the pre-compaction stress of soil } \\
\text { was measured with the method of searching the crossing point of } \\
\text { tangents with the secondary stress curve and the original stresses } \\
\text { curve (a classical method). It was found out that for samples } M \text { with the } \\
\text { degree of saturation of } 0.40-0.50 \text {, the pre-compaction stress does not } \\
\text { significantly depend on the plate diameter. For samples } M \text { or } N N S \text {, with } \\
\text { the degree of saturation of } 0.64-0.82 \text {, the pre-compaction stress signifi- } \\
\text { cantly depends on the diameter of the plate. A conclusion was formulat- } \\
\text { ed that in the research of } N G \text { with the method of uniaxial deformations, } \\
\text { the relation of the diameter of the plate }(d) \text { to the diameter of the cylin- } \\
\text { der }(D) \text { should be within } 0.5 \leq \mathrm{d} / \mathrm{D} \leq 0.8 \text {. }\end{array}$} \\
\hline $\begin{array}{l}\text { Key words: } \\
\text { soil, } \\
\text { moisture, } \\
\text { granulation type, } \\
\text { pre-compaction stress, } \\
\text { diameter of plate }\end{array}$ & \\
\hline
\end{tabular}

\section{Introduction}

Excessive soil compaction by machines and tractors leading to unfavourable changes in soil property is one of the most serious problems of the contemporary agriculture (Krasowicz et al., 2011). Soil compaction increases when the strength to compaction, which may be characterised with the pre-compaction stress, is exceeded. It is considered that

1 This publication was written as a part of the project financed from the funds of the National Centre of Science (Agreement no 7808/B/P01/2011/40) 
Dariusz Błażejczak, Jan B. Dawidowski

knowing the value of this stress allows forecasting pre-compaction loading of soil with driving mechanisms, the exceeding of which creates the threat of the increase of its compaction (Horn and Fleige, 2003). A utilitarian meaning of the pre-compaction stress causes that this parameter is the object of research in many centres in the world. The value of the pre-compaction stress of soil is determined based on the data obtained during soil loading when analysing the course of changes of its deformation as a function of the pressure made. However, the complexity of the soil environment and constant changes of its properties cause that the standard method of determination of this parameter has not been yet developed (Błażejczak, 2010).

The current research results do not give an explicit answer on what conditions are required to carry out the soil loading (Dawidowski et al., 2003, Śnieg et al., 2008, Błażejczak, 2009, Mosaddeghi et al., 2007). Thus, an attempt was made to investigate the impact of the diameter of the plate on the value of the determined pre-compaction stress of soil. Based on the measurements carried out on model samples made of the soil material with the granulation type of the silty clay it was found out that the relation of the diameter of the plate $(d)$ to the internal diameter of the cylinder should be within $0.3 \leq d / D<0.8$, and that the relation between the value of the determined pre-compaction stress of the sample and the plate diameter may be affected by the soil moisture (Błażejczak and Dawidowski, 2016). It was also found out that generalization of the obtained research results for other soil types requires further research. It is justified since during compaction in the zone of the plate impact on soil and in the zone of the soil impact on the walls of the steel cylinder, internal and external friction phenomena take place. It is commonly known that the internal friction resistance of the compact soil depends on its internal friction angle and compactness which assume various values in relation to the granulation type of soil and its moisture (Wiłun, 2003). In case of the impact of soil on the cylinder wall during its compaction the external friction phenomenon takes place, which is a derivative of the soil-metal friction coefficient. This coefficient depends on the granulation type of soil and its moisture (Domżał et al., 1978).

The impact of the granulation type of soil on the course of the compaction process has been known for many years (Holtz and Kovacs, 1981). In the recent years its impact on the determined value of the pre-compaction stress was also proved. Rücknagel et al., (2013) stated during research on the model samples with a varied granulation type that the obtained pre-compaction stress value is influenced by the content of gravel fraction. Also coefficients of the regression equation for predicting the pre-compaction stress value depend on the granulation type both in case of model samples produced in the laboratory (Saffih-Hdadi et al., 2009) as well as samples with the so-called intact structure (Błażejczak, 2010). The value of the pre-compaction stress is also affected by its mineralogical composition (Ajayi et al., 2013).

\section{Objective and scope and methods of research}

The objective of the paper was to verify the previously obtained results of research concerning the impact of the plate diameter on the measured value of the pre-compaction stress of samples of silt (NG), in conditions of a wider range of soil species and their initial stage. 
Impact of the plate diameter...

The research material was collected from the selected soils of Nizina Szczecińska [Szczecin Valley] in the form of loose soil mass with the use of steel cylinders (further called samples with intact structure). The material was collected from sublayers of subsoil with the thickness of $5 \mathrm{~cm}$ located at the depth of 25 to $60 \mathrm{~cm}$, in the period of spring or autumn field machinery works from the rural areas (sites) of: Obojno (Ob), Ostoja (Os), Skarbimierzyce (Sk), Reńsko (Re), Nowy Przylep ( $N p)$, Kurcewo $(K u)$. Depth of collection of samples depended on the present moisture level which guaranteed obtaining research material of the proper quality. In case of samples whose structure was intact only those were qualified to further research in which no soil cracks in the cylinder were reported.

Loose soil material served for determination of the investigated soil properties and for production of model samples $(M)$. The textural group was determined acc. to USDA (2009) with Bouyoucos-Casagrande's method in Prószyński's modification (sand fractions were washed on the sieve with meshes dimension of $0.1 \mathrm{~mm}$ ). A pycnometer method was used for determination of the solid phase density. The humus content was determined with Tiurin's method and soil reaction with electrometric method. The content of calcium carbonate was marked with Scheibler method - if the presence of $\mathrm{CaCO}_{3}$ was determined during the first assessment of the effervescence reaction in the presence of hydrochloric acid. The plastic limit was measured with the rolling method and the liquid limit with the use of Cassagrande's apparatus.

Three soils (sites) with clearly varied properties were selected for production of the model samples. Production of the model samples consisted of sieving moist material through the sieve with $6 \mathrm{~mm}$ diameter and then uniaxial compression in stiff steel rings (cylinders). The produced samples had a diameter and height respectively of 100 and 30 $\mathrm{mm}$. Mass of the soil material for filling the cylinder was selected in order to obtain the volumetric density of model samples similar to the density of samples with intact structure, determined in these soils during previous field research (Błażejczak et al., 2010).

Samples with the intact structure (NNS) were collected from the investigated soils (sites) with the use of cylinders whose internal diameter and height were respectively 100 and $30 \mathrm{~mm}$.

In samples $M$ and $N N S$ the following properties were determined: water moisture content and dry density of solid particles, porosity of aeration, plastic degree, degree of saturation. Moreover, the ratio of moisture to the moisture corresponding to the plastic limit of the investigated soils was calculated.

Both samples $M$ and NNS were subjected to the load with the use of a testing machine with plates of varied diameters $(d)$. In case of samples $M$, the analysis of results obtained during the previous research (Błażejczak and Dawidowski 2016) allowed limitation of the number of plates and iterations. Tests on samples $M$ were carried out in three iterations with the use of plates with the following diameters: 20; 30; 50; 70; 80; 90 and $98 \mathrm{~mm}$. Results obtained in samples $M$ allowed, on the other hand, to limit the number of plates' sizes used for deformation of samples NNS. Tests in the NNS samples were carried out in five iterations with the use of plates with the following diameters: 30; 50; 80; and $98 \mathrm{~mm}$. The recorded courses of unit stress of plates from deformation of samples served for determination of their pre-compaction stress. The value of pre-compaction stress of soil $(N G)$ was determined with the so-called classical method (Błażejczak and Dawidowski, 2016). In order to select a range of diameters where the size of the applied plate does not affect the value of the determined pre-compaction stress a single factor analysis of variance with post-hoc 
Dariusz Błażejczak, Jan B. Dawidowski

Tukey's test was applied. Division into uniform groups was carried out with the use of $\alpha=0.05$. Calculations were carried out in Excel and Statistica programmes.

\section{Research results and their analysis}

Table 1 includes the results of measurement of the selected properties of the investigated soils. One may notice that they take varied values. Specific density of solid phase is within $2.43-2.66 \mathrm{~g} \cdot \mathrm{cm}^{-3}$. Reaction is from $\mathrm{pH} 5.08$ to $\mathrm{pH}$ 6.94. The humus and calcium carbonate content, the values of plastic and liquid limit are respectively within: 0.49 $3.77 \%, 0.00-5.00 \%, 14.1-28.0 \%$ and $17.0-47.9 \%$ Also the textural group of soil is varied. The content of sand, clay and silt were changing within: $25.0-60.5 \%, 24.5-52.4 \%$ and $8.9-27.0 \%$. Based on the analysis of the plasticity ratio value (difference: $w_{\mathrm{L}}-w_{\mathrm{P}}$ ) the investigated soil should be included to formations which are low or average cohesive (Wiłun, 2003).

Table 1.

Results of measurement of properties of investigated soils

\begin{tabular}{|c|c|c|c|c|c|c|c|c|c|c|c|}
\hline \multirow{3}{*}{$\stackrel{\vec{*}}{*}$} & \multirow{3}{*}{$\begin{array}{c}\text { Type } \\
\text { of samples }\end{array}$} & \multirow{3}{*}{$\begin{array}{c}\text { Layer } \\
(\mathrm{cm})\end{array}$} & \multirow{3}{*}{$\begin{array}{c}\rho_{\mathrm{s}} \\
\left(\mathrm{g} \cdot \mathrm{cm}^{-3}\right)\end{array}$} & \multirow{3}{*}{ 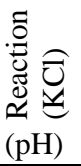 } & \multirow[t]{3}{*}{$Z_{\mathrm{pr}}$} & \multirow[t]{2}{*}{$\mathrm{CaCO}_{3}$} & \multirow[t]{2}{*}{$w_{\mathrm{P}}$} & \multirow[t]{3}{*}{$w_{\mathrm{L}}$} & \multicolumn{3}{|c|}{$\begin{array}{l}\text { Fraction acc. to } \\
\text { PTG (2009) }\end{array}$} \\
\hline & & & & & & & & & Sand & Silt & Clay \\
\hline & & & & & & (\%) & $(\% \mathrm{w} / \mathrm{w})$ & & & (\%) & \\
\hline $\mathrm{Np}$ & $M, N N S$ & $35-40$ & 2.46 & 6.34 & 2.02 & 2.50 & 21.3 & 31.2 & 36.9 & 52.4 & 10.7 \\
\hline $\mathrm{Ob}$ & $M, N N S$ & $35-40$ & 2.49 & 6.84 & 3.77 & 0.04 & 28.0 & 47.9 & 25.0 & 48.0 & 27.0 \\
\hline Os & $M$ & $35-40$ & 2.66 & 5.10 & 0.60 & 0.00 & 18.4 & 27.6 & 45.0 & 40.3 & 14.7 \\
\hline Os & NNS & $25-30$ & 2.52 & 5.08 & 1.03 & 0.00 & 14.1 & 17.0 & 60.5 & 30.6 & 8.9 \\
\hline $\mathrm{Ku}$ & NNS & $25-30$ & 2.66 & 6.94 & 0.49 & 0.00 & 15.2 & 18.9 & 52.5 & 28.7 & 18.8 \\
\hline $\operatorname{Re}$ & NNS & $25-30$ & 2.43 & 6.21 & 3.32 & 5.00 & 23.5 & 32.2 & 37.5 & 50.6 & 11.9 \\
\hline Sk & NNS & $25-30$ & 2.50 & 6.23 & 1.78 & 0.00 & 21.8 & 39.2 & 54.0 & 24.5 & 21.5 \\
\hline
\end{tabular}

Symbols: $M$ - samples produced in laboratory, $N N S$ - samples with intact structure, $\rho_{\mathrm{s}}$ - relative density, $Z_{\mathrm{pr}}-$ humus content, $\mathrm{CaCO}_{3}-$ content of calcium carbonate $w_{\mathrm{P}}$ - plastic limit, $w_{\mathrm{L}}-$ liquid limit

Table 2 contains results of measurements of soil samples properties produced in laboratory conditions. Moisture of samples (w) was lower than the plastic limit (tab. 1). Value of dry density of solid particles was i.e. from 1.42 to $1.46 \mathrm{~g} \cdot \mathrm{cm}^{-3}$. The remaining properties of samples $M$ were more varied. But the biggest differences occurred between the properties of the samples of facility $N p$ and $O b$. Based on the analysis of the plasticity level $\left(I_{\mathrm{L}}\right)$ it should be stated that all samples $M$ were loaded in the semi-solid state (Wiłun, 2003). 
Impact of the plate diameter...

Table 2.

Results of measurements of soil samples properties (M) produced in laboratory conditions

\begin{tabular}{|c|c|c|c|c|c|}
\hline \multirow[t]{2}{*}{ Site } & \multirow{2}{*}{$\begin{array}{c}w \\
(\% \mathrm{w} / \mathrm{w}) \\
\end{array}$} & \multirow{2}{*}{$\begin{array}{c}\rho_{\mathrm{d}} \\
\left(\mathrm{g} \cdot \mathrm{cm}^{-3}\right)\end{array}$} & \multirow{2}{*}{$\begin{array}{c}n_{\mathrm{a}} \\
(\%)\end{array}$} & $I_{\mathrm{L}}$ & $S_{\mathrm{r}}$ \\
\hline & & & & \multicolumn{2}{|c|}{$(-)$} \\
\hline$N p$ & 19.1(0.6) & $1.46(0.05)$ & $12.5(2.3)$ & $-0.22(0.06)$ & $0.69(0.05)$ \\
\hline$O b$ & 23.1(0.3) & $1.42(0.01)$ & $10.3(0.7)$ & $-0.25(0.02)$ & $0.76(0.01)$ \\
\hline Os & $12.7(0.1)$ & $1.46(0.01)$ & $26.5(0.6)$ & $-0.62(0.01)$ & $0.41(0.01)$ \\
\hline
\end{tabular}

Symbols: $w$ - water moisture content, $\rho_{\mathrm{d}}$ - dry density of solid particles, $n_{\mathrm{a}}$ - porosity of aeration $I_{\mathrm{L}}-$ plasticity level, $S_{\mathrm{r}}$ - degree of saturation; Notice: the brackets provide the value of the standard deviation

When analysing the properties of the soil samples with intact structure (table 3) one may notice that their values were more varied than the values of samples $M$. It was expected on account of varied properties of investigated soils (see table 1). In case of Ostoja and Skarbimierzyce sites, the research were carried out in two time limits which was marked as Os-1 and Os-2 andSk-1 and Sk-2. For Os-1 and Os-2 properties of samples were similar and for $S k-1$ and $S k-2$ they differed with moisture, which allowed more complete verification of previous results of research. Based on the analysis of the plasticity level $\left(I_{\mathrm{L}}\right)$ one should state, that the NNS samples were subjected to loading in a varied state - from semi- solid to the plastic one (Wiłun, 2003).

Table 3.

Results of measurements of properties of samples with intact structure (NNS)

\begin{tabular}{|c|c|c|c|c|c|}
\hline \multirow{2}{*}{ Site } & \multirow{2}{*}{$\begin{array}{c}w \\
(\% \mathrm{w} / \mathrm{w})\end{array}$} & \multirow{2}{*}{$\begin{array}{c}\rho_{\mathrm{d}} \\
\left(\mathrm{g} \cdot \mathrm{cm}^{-3}\right)\end{array}$} & \multirow{2}{*}{$\begin{array}{c}n_{\mathrm{a}} \\
(\%)\end{array}$} & $I_{\mathrm{L}}$ & $S_{\mathrm{r}}$ \\
\hline & & & & \multicolumn{2}{|c|}{$(-)$} \\
\hline$K u$ & 17.1(1.6) & $1.52(0.07)$ & $14.4(5.1)$ & $0.55(0.42)$ & $0.65(0.12)$ \\
\hline$N p$ & 21.1(1.4) & $1.49(0.07)$ & $7.9(5.1)$ & $-0.02(0.14)$ & $0.81(0.11)$ \\
\hline$O b$ & $22.4(0.7)$ & $1.52(0.00)$ & $4.9(1.9)$ & $-0.28(0.03)$ & $0.87(0.04)$ \\
\hline Os-1 & $15.0(0.9)$ & $1.67(0.04)$ & $8.4(1.8)$ & $0.32(0.30)$ & $0.75(0.05)$ \\
\hline Os-2 & $15.3(1.2)$ & $1.63(0.10)$ & $10.2(3.0)$ & $0.40(0.41)$ & $0.71(0.06)$ \\
\hline$R e$ & $25.5(0.8)$ & $1.34(0.10)$ & $10.7(3.4)$ & $0.23(0.10)$ & $0.77(0.07)$ \\
\hline$S k-1$ & $13.2(0.9)$ & $1.66(0.07)$ & $12.0(2.5)$ & $-0.50(0.05)$ & $0.64(0.04)$ \\
\hline$S k-2$ & $17.0(0.9)$ & $1.65(0.06)$ & $6.2(2.7)$ & $-0.28(0.05)$ & $0.82(0.07)$ \\
\hline
\end{tabular}

Notice: brackets include the value of standard deviation. Symbols - see table 2. 
Dariusz Błażejczak, Jan B. Dawidowski

Table 4 includes the results of calculations of pre-compaction stress of soil samples produced in laboratory conditions and the post-hoc Tukey's test. One may notice that in case of samples of sites $N p$ and $O b$, which have a relatively high value of ratio $w / w_{\mathrm{p}}$, amounting respectively to 0.92 and 0.82 , the value of the measured $N G$ depends significantly on the diameter of the plate used for soil deformation. Within the sites $N p$ and $O b$ several uniform groups of $N G$ values were determined. For samples from the facility $O s$ for which the ratio $w / w_{\mathrm{p}}$ was 0.69 it was found out that the calculated $N G$ value does not significantly depend on the plate diameter used for deformation of soil - all values may be included to the same uniform group. These results are thus compliant with the results obtained in the previous paper (Błażejczak and Dawidowski, 2016), which proved that the significant impact of the diameter of plate on the determined value of pre-compaction stress of soil is observed when the moisture of samples is close to their plastic limit value.

By analysing of the $N G$ value and their standard deviations in relation to the diameter of the plate ( $d$ ) one may also notice (tab. 4), that:

- differences between the $N G$ values of samples within the sites $N p, O b$, Os are not statistically significant, respectively within the diameters of plates: 50 - 90 and $70-98 ; 30$ 90 and 50 - 98; 20 - $98 \mathrm{~mm}$;

- the highest $N G$ values for the soil in sites $N p$ and $O b$ were reported for the plates $d 20$;

- range of results for $N G$, measured with standard deviation is the highest for plates $d 20$ or $d 30$, but it may be also raised for $d 98$ (site $O b$ ),

- results obtained for sites $N p$ and $O b$, with the use of plates $d 20$ or $d 98$, were included to uniform groups with the lowest or the highest value measured $N G$;

- results of $N G$ obtained for the diameter of the plate $d 30$ do not differ significantly from the results obtained for $d 20$ (exception $O b$ ) or $d 50$;

- results of $N G$ obtained for the diameter of the plate $d 90$ do not differ significantly from the results obtained for $d 80$ or $d 98$;

- for sites $N p$ and $O b$, with the use of plate $d 98$, an explicit but insignificant decrease of measured values $N G$ was reported, in comparison to the values measured for $d 90$;

- for the site $N p$ a noticeable but statistically insignificant decrease of the measured values of $N G$ for the plate $d 90$ was reported, which is also noticed for the plate $d 98$.

The research carried out on samples produced in laboratory conditions $(M)$ partially confirm the previous results (Błażejczak and Dawidowski, 2016), because based on the analysis of results presented in table 4 , one should assume that the ratio of $d / D$ should be within $0.3<d / D \leq 0.9$ and not $0.3 \leq d / D<0.8$. However the analysis of results obtained for the Os site (table 4) allows stating that omission of the above condition is possible in the situation when soil is low compacted - the difference between $w_{\mathrm{L}}$ and $w_{\mathrm{P}}$ is from 1 to $10 \%$ (tab. 1) - and water saturation is relatively low $S_{\mathrm{r}}=0.41$ (tab. 3). 
Impact of the plate diameter...

Table 4.

The value of pre-compaction stress of soil samples $(M)$, produced in laboratory conditions for particular diameters of plates with a division into uniform groups

\begin{tabular}{|c|c|c|c|c|c|c|c|c|c|}
\hline \multirow{3}{*}{ Site } & \multirow{3}{*}{$\begin{array}{c}\text { Textural } \\
\text { group acc. } \\
\text { to } \\
\text { PTG/USDA } \\
\text { (PTG 2009) }\end{array}$} & \multirow{3}{*}{$\begin{array}{c}w / w_{p} \\
(-)\end{array}$} & \multicolumn{7}{|c|}{ Diameter of plate (mm) } \\
\hline & & & 20 & 30 & 50 & 70 & 80 & 90 & 98 \\
\hline & & & \multicolumn{7}{|c|}{ Pre-compaction stress $(\mathrm{kPa})$} \\
\hline$N p$ & pyg/SiL & $0.90(0.03)$ & $\begin{array}{l}318 d \\
(22)\end{array}$ & $\begin{array}{c}\text { 288cd } \\
\text { (17) }\end{array}$ & $\begin{array}{c}258 \mathrm{bc} \\
\text { (10) }\end{array}$ & $\begin{array}{c}234 a b \\
(7)\end{array}$ & $\begin{array}{c}\text { 245ab } \\
\text { (13) }\end{array}$ & $\begin{array}{c}\text { 221ab } \\
\text { (14) }\end{array}$ & $\begin{array}{c}214 a \\
(8)\end{array}$ \\
\hline$O b$ & $\mathrm{gz} / \mathrm{L}$ & $0.82(0.01)$ & $\begin{array}{c}394 c \\
(10)\end{array}$ & $\begin{array}{c}339 b \\
(23)\end{array}$ & $\begin{array}{c}317 a b \\
\text { (21) }\end{array}$ & $\begin{array}{c}294 a b \\
(12)\end{array}$ & $\begin{array}{c}295 a b \\
(9)\end{array}$ & $\begin{array}{c}316 a b \\
\text { (4) }\end{array}$ & $\begin{array}{l}284 a \\
(20)\end{array}$ \\
\hline Os & $\mathrm{gz} / \mathrm{L}$ & $0.69(0.00)$ & $\begin{array}{l}60 \mathrm{a} \\
(8)\end{array}$ & $\begin{array}{l}64 a \\
(13)\end{array}$ & $\begin{array}{l}59 a \\
(8)\end{array}$ & $\begin{array}{l}57 a \\
(9)\end{array}$ & $\begin{array}{r}59 a \\
(10)\end{array}$ & $\begin{array}{l}67 a \\
(9)\end{array}$ & $\begin{array}{c}63 a \\
(7) \\
\end{array}$ \\
\hline
\end{tabular}

Symbols: pyg/SiL - pył gliniasty/silt loam, gz/L - glina zwykła/loam, gz/L - glina zwykła/loam, Notice: uniform groups were marked with small letters $\alpha=0,05$; brackets include the value of standard deviation

Table 5 includes the results of calculations of NG and Tukey's post-hoc test of soil samples with intact structure. One may notice that the impact of soil moisture on the relation between the value of the measured pre-compaction stress and the diameter of the plate is not explicit. It was expected that for lower values of the ratio $w / w_{\mathrm{p}}$ this impact will not be material and when the soil moisture will be close to its plastic limit, the result will be contrary. In case of Skarbimierzyce site from which samples were collected in two dates (Sk-1, $S k$-2) the impact of the soil moisture on the relation between the $N G$ value and the diameter of the plate is clear for majority of its values. The nature of the obtained results indicates however the partially reverse situation, because for the higher moisture $(S k-2)$ the indicated $N G$ values, except the results obtained for the plate $d 30$, were included to one uniform group. Similarly as for the site $S k-2$, a weak impact of the soil moisture on the relation between the value of the $N G$ determined and the diameter of the plate was obtained for the sites $N p$ and $R e$, whose textural group was included into the same group - silt loam.

By analysing shaping of the value $N G$ and their standard deviations in relation to the diameter of the plate $(d)$ one may also notice (tab. 5), that:

- the highest values of $N G$ were the most often reported for the plate $d 30$ (exception: $K u$ ),

- values of $N G$ calculated for the plates $d 50$ and $d 80$ do not differ significantly,

- for the plate $d 98$ the increase of the $N G$ value was often obtained after its decrease to $d 50$ and $d 80$ (exceptions: Os-2, Re),

- range of values of $N G$, measured with standard deviations was often the highest for the plate $d 30$ (exception: Os-2),

- for $d 98$ often the increased range of values of $N G$ in comparison to the results obtained for $d 80$, was reported (exceptions: $K u$ and $S k-1$ ).

Analysis of the results obtained for samples with the so-called intact structure (table 5) allows finding out that they confirm previous results, similarly to the ones reported for the samples produced in laboratory conditions (table 4), (Błażejczak and Dawidowski, 2016). In this case one should assume however, that the ratio of $d / D$ should be within the range of $0.5 \leq d / D \leq 0.8$, because the most often significant changes of $N G$ occurred between the values measured for plates $d 30$ and $d 50$. 
Dariusz Błażejczak, Jan B. Dawidowski

Table 5.

Pre-compaction stress value of soil samples with intact structure (NNS) for particular plate diameters divided into uniform groups

\begin{tabular}{|c|c|c|c|c|c|c|}
\hline \multirow{3}{*}{ Site } & \multirow{3}{*}{$\begin{array}{l}\text { Textural group acc. } \\
\text { to PTG/USDA } \\
\text { (PTG 2009) }\end{array}$} & \multirow{3}{*}{$\begin{array}{c}w / w_{p} \\
(-)\end{array}$} & \multicolumn{4}{|c|}{ Diameter of the plate (mm) } \\
\hline & & & 30 & 50 & & 98 \\
\hline & & & \multicolumn{4}{|c|}{ Pre-compaction stress $(\mathrm{kPa})$} \\
\hline \multirow[t]{2}{*}{$\mathrm{Ku}$} & \multirow{2}{*}{$\mathrm{gl} / \mathrm{SL}$} & \multirow[t]{2}{*}{$1,14(0,11)$} & 71ab & $79 b$ & $57 a b$ & $45 a$ \\
\hline & & & $(17)$ & $(16)$ & $(14)$ & (9) \\
\hline \multirow[t]{2}{*}{$\mathrm{Np}$} & \multirow{2}{*}{ pyg/SiL } & \multirow[t]{2}{*}{$0,99(0,06)$} & $156 b$ & $79 a$ & $65 a$ & $71 \mathrm{a}$ \\
\hline & & & $(30)$ & $(15)$ & $(7)$ & $(15)$ \\
\hline \multirow[t]{2}{*}{$\mathrm{Ob}$} & \multirow{2}{*}{$\mathrm{gz} / \mathrm{L}$} & \multirow[t]{2}{*}{$0,80(0,02)$} & $116 \mathrm{c}$ & $46 a$ & 51ab & 91bc \\
\hline & & & $(39)$ & $(12)$ & $(14)$ & $(20)$ \\
\hline \multirow[t]{2}{*}{ Os-1 } & \multirow{2}{*}{$\mathrm{gl} / \mathrm{SL}$} & \multirow[t]{2}{*}{$1,07(0,06)$} & $176 b$ & $116 a$ & $126 a$ & $135 \mathrm{ab}$ \\
\hline & & & $(26)$ & $(17)$ & (16) & $(38)$ \\
\hline \multirow[t]{2}{*}{ Os-2 } & \multirow{2}{*}{$\mathrm{gl} / \mathrm{SL}$} & \multirow[t]{2}{*}{$1,08(0,08)$} & $132 b$ & $122 \mathrm{ab}$ & 103ab & $72 a$ \\
\hline & & & $(30)$ & $(40)$ & $(20)$ & $(25)$ \\
\hline \multirow[t]{2}{*}{$\operatorname{Re}$} & \multirow{2}{*}{ pyg/SiL } & \multirow[t]{2}{*}{$1,09(0,04)$} & $111 b$ & $46 a$ & $54 a$ & $42 a$ \\
\hline & & & $(23)$ & $(10)$ & $(15)$ & $(17)$ \\
\hline \multirow[t]{2}{*}{$\overline{\text { Sk-1 }}$} & \multirow{2}{*}{ gpi/SCL } & \multirow[t]{2}{*}{$0,60(0,04)$} & $160 \mathrm{~b}$ & 124ab & $79 a$ & 110ab \\
\hline & & & $(41)$ & (36) & (14) & (13) \\
\hline \multirow[t]{2}{*}{ Sk-2 } & \multirow{2}{*}{ gpi/SCL } & \multirow[t]{2}{*}{$0,78(0,04)$} & $133 b$ & 83a & $69 a$ & $81 a$ \\
\hline & & & (34) & (23) & $(20)$ & (25) \\
\hline
\end{tabular}

Symbols gl/SL - glina lekka/sandy loam, pyg/SiL - pył gliniasty/silt loam, gz/L - glina zwykła/loam, gpi/SCL glina piaszczysto-ilasta/sandy clay loam; Notice: uniform groups were marked with small letter with $\alpha=0.05$; the brackets include the value of standard deviation

\section{Conclusions}

Based on the analysis of research results obtained in this paper and their comparison with the results obtained earlier by Błażejczak and Dawidwski (2016) the following conclusions can be made:

1. In case of soil material which had low compactness and whose texture is silt clay or clay and with moisture equal to 0.49 or 0.69 of the plastic limit of soil, the determined value of pre-compaction stress of the model samples does not significantly depend on the plate diameter used for their deformation if the degree of saturation and porosity of aeration are ca. respectively within: $0.40-0.50$ and $16-27 \%$.

2. In case of low and medium-solid soils - silt loam, loam, light loam, sand loam and the moisture equal to 0.60 or 1.14 of the plastic limit of soil - the determined value of precompaction stress of soil significantly depends on the diameter of the plate used for deformation of model samples or samples with an intact structure if their degree of saturation and porosity of aeration is respectively within: $0.64-0.82,4.9-14.4 \%$.

3. In case of determination of the pre-compaction stress of soil with the use of cylinders with the diameter $(D)$ of $100 \mathrm{~mm}$ and the height of $30 \mathrm{~mm}$, one may avoid the impact of the diameter of the plate $(d)$ on the results of measurement when the $d / D$ ratio is within $0.5 \leq$ $d / D \leq 0.8$. 
Impact of the plate diameter...

4. Generalization of the results obtained so far requires further research especially with reference to various heights of samples.

\section{References}

Ajayi, A.E., Dias Junior, M.S., Curi, N., Oladipo, I. (2013). Compressive response of some agricultural soils influenced by the mineralogy and moisture. International Agrophysics, 27, 239-246.

Błażejczak, D. (2009). Naprężenie graniczne próbek gleby o nienaruszonej strukturze w zależności od warunków ich odkształcania. Inżynieria Rolnicza, 5(114), 33-40.

Błażejczak, D. (2010). Prognozowanie naprężenia granicznego $w$ warstwie podornej gleb ugniatanych kołami pojazdów rolniczych. Wydawnictwo Uczelniane ZUT w Szczecinie. ISBN 978-837663-050-2.

Błażejczak, D., Dawidowski, J.B. (2016). Wpływ średnicy stempla na wyznaczaną wartość naprężenia granicznego próbek wytworzonych z gleby pylastej. Agricultural Engineering, 2(158), 5-14.

Dawidowski, J.B., Śnieg, M., Błażejczak, D., Morrison, Jr. J.E. (2003). Procedure on Indicated Values of Soil Precompaction Stress. Proceedings of 16th Triennial Conference of International Soil Tillage Organisation: Soil Management for Sustainability, 13-18 July 2003, The University of Queensland, Brisbane, Australia, 344-350.

Domżał, H., Słowińska-Jurkiewicz, A., Turski, R. (1978). Gleboznawstwo z elementami geologii i mechaniki gleby. Wyd. Akademii Rolniczej w Lublinie.

Holtz, R. D., Kovacs, W. D. 1981. An introduction to geotechnical engineering. Prentice-Hall Inc., Englewood Cliffs, New Jersey, ISBN 0-13-484394-0.

Horn, R., Fleige, H. (2003). A method for assesing the impact of load on mechanical stability and on physical properties of soils. Soil \& Tillage Research, 73, 89-99.

Krasowicz, S., Oleszek, W., Horabik, J., Dębicki, R., Jankowiak, J., Stuczyński, T., Jadczyszyn, J., (2011): Racjonalne gospodarowanie środowiskiem glebowym Polski. Polish Journal of Agronomy, 7, 43-58.

Krümmelbein, J., Peth, S., Horn, R. (2008). Determination of pre-compression stress of variously grazed steppe soil under static and cyclic loading. Soil \& Tillage Research, 99, 139-148.

Mosaddeghi M.R.,, Koolen, A.J., Hemmat, A., Hajabbasi ,M.A., Lerink, P. (2007). Comparisons of different procedures of pre-compaction stress determination on weakly structured soils. Journal of Terramechanics, 44, 53-63.

Polskie Towarzystwo Gleboznawcze (2009). Klasyfikacja uziarnienia gleb i utworów mineralnych PTG 2008. Roczniki Gleboznawcze, 60(2), 5-16.

Rücknagel, J., Hofmann, B., Paul, R., Christen, O., Hulsbergen, K. J. (2007). Estimating precompression stress of structured soils on the basis of aggregate density and dry bulk density. Soil \& Tillage Research, 92, 213-220.

Saffih-Hdadi, K., De'fossez, P., Richard, G., Cui, Y.-J., Tang, A.-M., Chaplain, V. (2009). A method for predicting soil susceptibility to the compaction of surface layers as a function of water content and bulk density. Soil \& Tillage Research, 105, 96-103.

Śnieg, M., Błażejczak, D., Dawidowski, J. B., Tomaszewicz, T. (2008). Badanie podatności na zagęszczanie podornej warstwy czarnej ziemi gliniastej. Inżynieria Rolnicza, 5(103), 315-322.

Wiłun, Z. 2003. Zarys geotechniki. WKiŁ, Warszawa, ISBN 83-206-1354-X. 
Dariusz Błażejczak, Jan B. Dawidowski

\section{WPLYW ŚREDNICY STEMPLA NA WARTOŚĆ NAPREŻ̇ENIA GRANICZNEGO W GLEBACH O ZRÓŻNICOWANYM UZIARNIENIU}

Streszczenie. Celem pracy była weryfikacja wcześniej uzyskanych wyników badań, dotyczących wpływu średnicy stempla na wyznaczaną wartość naprężenia granicznego gleby pylastej $(N G)$, w warunkach szerszego spektrum gatunków gleb i ich stanu początkowego. Badania przeprowadzono na próbkach o średnicy $100 \mathrm{~mm}$ i wysokości $30 \mathrm{~mm}$, wytwarzanych z materiału glebowego $(M)$ lub pobieranych z warstwy podornej wybranych gleb (NNS) o uziarnieniach: pyłu gliniastego, gliny zwykłej, gliny lekkiej, gliny piaszczysto-ilastej. Oznaczono następujące cechy gleb: skład granulometryczny, gęstość fazy stałej, zawartość próchnicy i węglanu wapnia, odczyn, granicę plastyczności i płynności. Właściwości próbek opisano: wilgotnością, gęstością objętościową szkieletu, porowatością aeracji, stopniem plastyczności i stopniem wilgotności. Próbki obciążano za pomocą maszyny wytrzymałościowej stemplami o zróżnicowanych średnicach. Wartość $N G$ gleby wyznaczano metodą poszukiwania punktu przecięcia stycznych do krzywej naprężeń wtórnych i krzywej naprężeń pierwotnych (metoda klasyczna). Stwierdzono, że dla próbek $M$, o stopniu wilgotności $0,40-0,50, N G$ nie zależy istotnie od średnicy stempla. Dla próbek $M$ lub NNS, o stopniu wilgotności 0,64-0,82, $N G$ zależy istotnie od średnicy stempla. Sformułowano wniosek, że w badaniach $N G$ metodą jednoosiowych odkształceń stosunek średnicy stempla $(d)$ do średnicy cylindra $(D)$ powinien mieścić się w przedziale $0,5 \leq \mathrm{d} / \mathrm{D}$ $\leq 0,8$.

Słowa kluczowe: gleba, wilgotność, uziarnienie, naprężenie graniczne, średnica stempla 